\title{
Welcome to OBESITy Facts, the Official Journal of the European Association for the Study of Obesity (EASO)!
}

\author{
Johannes Hebebrand \\ Department of Child and Adolescent Psychiatry and Psychotherapy, University of Duisburg-Essen, Essen, Germany
}

\begin{abstract}
Welcome to this very first issue of OBESITY FACTS, the new journal on obesity published by S. Karger, Freiburg i.Br./Basel. You may well ask: 'Why another new scientific journal at a time when the number of medical journals and newsletters is growing and funds for subscriptions are dwindling?' The answer is straight forward: Obesity has become one of the most rapidly expanding research fields. Our new journal will provide practical, timely, and state-of-the-art contributions from all continents on all aspects of obesity. There are many challenges for researchers interested in understanding the links between nutrition, genetics, and health and for those assessing the benefits of obesity prevention and treatment. As relevance and prevalence of obesity worldwide continues to grow, the need for a journal promoting interdisciplinary research in the field becomes greater. We strongly feel that these are compelling reasons which justify launching a new journal.
\end{abstract}

The aim of this international and peer-reviewed journal is to provide a platform, via which clinicians and researchers can share their experiences and latest findings in clinical and basic research, serving as a bridge to connect all disciplines contributing to obesity research. We feel confident that OBEsITY FACTS will prove to be valuable not only to increase multi- and interdisciplinary knowledge but also to help manage patients more optimally. The intention is to span the whole field of obesity life sciences, including epidemiology, etiology and pathogenesis, treatment, and the prevention of adiposity. With this broad sweep, the new journal will pull together what is now published in a number of different journals, and indeed some material for which it is difficult to find a home.

Experts in the areas encompassed by the journal's scope have been identified for the Editorial Board, and the composition of the board will be continually updated to address the developments in this exciting field.

Issues will contain reviews, original articles, case reports, book reviews, guidelines, congress reports etc. At present OBEsITY
FACTS is published bimonthly online (ISSN 1662-4033) and in print (ISSN 1662-4025), but our aim is to appear on a monthly basis in the near future. Due to the fast track system, the span between submission of a paper and its publication can be kept short. Accepted articles will appear online first as prepublication. Go to www.karger.com/ofa to see for yourself!

Before we briefly dwell on the contents of the first issue, we would like to give the reader a short account of the events that have preceded this publication. At the beginning of 2006 the Karger publishing house had the initial idea to launch an obesity journal to be published mainly in German-speaking countries. Papers were to appear either in English or German. Over the next 15 months the idea was looked at from several points of view, especially the market was researched. Several potential editors-in-chief were contacted by Karger; Johannes Hebebrand was one of them. Before accepting this position in August 2007, he made a couple of calls; it rapidly became clear that a half German, half English journal would not really take off. As a consequence it was agreed that English was to be the sole language of the peer-reviewed papers. The title of the journal was agreed upon early on; if you as a reader should ever stumble across fiction instead of facts, please send us a letter, which we vow to publish if we indeed did not stick to our title. The Editor-in-Chief and the Publisher subsequently rapidly contacted several potential associate editors and editorial board members who fortunately just as rapidly decided to come aboard. We also contacted Thorkhild Sørensen from Copenhagen, who told us that the European Association of Obesity (EASO) was looking for a publisher to launch the European Journal of Obesity. Thorkhild Sørensen proved invaluable in establishing contacts to EASO, which resulted in a meeting in early November 2007 of Vojtech Hainer, the current president of EASO, Euan Woodward, Acting Executive Director of EASO, Thorkhild Sørensen, Johannes Hebebrand, and Karger representatives. On December 6, 2007, it finally

\begin{tabular}{ll}
\hline KARGER & ๑ 2008 S. Karger GmbH, Freiburg \\
$\begin{array}{l}\text { Fax +497614520714 } \\
\begin{array}{l}\text { E-mail Information@Karger.de } \\
\text { www.karger.com }\end{array}\end{array}$ & $\begin{array}{c}\text { Accessible online at: } \\
\text { www.karger.com/ofa }\end{array}$ \\
&
\end{tabular}

Prof. Dr. Johannes Hebebrand 
was decided that OBESITY FACTS would become the official journal of EASO, with the subtitle reading 'The European Journal of Obesity'.

As a result, OBESITY FACTS has gained considerable momentum prior to this very first issue. We are already receiving original articles from Europe and the USA; we are certain that our initial success will help us to provide researchers in the field of obesity with a platform via which their results/reviews can be disseminated rapidly to the scientific community.

The contents of the first issue of OBESITY FACTS reflects our intention to cover a wide range of obesity-related topics.

Stefan Engeli [1] reviews the peripheral endocannabinoid system, which has become increasingly more relevant. Seemingly, some of the long-term metabolic effects of rimonabant can be linked to this peripheral system.

Anja Hilbert et al. [2] have managed to assemble an interdisciplinary team to in-depth tackle the complex issues related to the prevention of obesity. The authors stem from the fields of psychology, medicine, law, economics, and social ethics. They point out implications of genetic research into body weight regulation for prevention and discuss to what extent an individual is responsible for his or her overweight. From an economic perspective they argue that networking is superior to both incentives for healthy food and taxation of unhealthy foods. Finally, they favor individualized psychological treatments.

Anke Hinney and Johannes Hebebrand [3] have summarized the recent advancements in the dissection of polygenic obesity. It is becoming increasingly clear that many gene variants - each with a small effect size - account for the genetic basis of obesity in most affected individuals. The revolution brought upon by the recent development and large-scale use of DNA chips will entail the identification of several novel variants within the upcoming months. For this purpose, collaborations among different groups are required; validation efforts require DNA samples from not only thousands but ten thousands of individuals. The currently most important polygene termed 'Fat Mass and Obesity Associated' (FTO) was linked to obesity by Frayling et al. [4] in 2007. Prior to the discovery of the important role of FTO in obesity, Ulrich Rüther and colleagues in Düsseldorf had localized this large gene to mouse chromosome 8 based on their work on mice with a malformation of both fore limbs due to a large deletion encompassing five additional genes. Rüther's group provides a first hand account of how research into FTO was initiated in 1989 [5]; it is mere coincidence nevertheless attests to great foresight - that Rüther and coworkers originally had termed this large gene as fatso.

Our very first original research article stems from the group of Manfred Müller: Britta Hitze and coworkers [6] analyzed the effect of overweight, waist circumference and dietary habits on the postprandial triglyceride response in men aged 44 to 68 years. They also compared this response with fasting triglyceride levels. Overweight, abdominal fat and a low intake of dietary fiber proved to be determinants of an increased postprandial triglyceride response. In contrast to findings obtained in younger normal-weight men, fasting triglyceride levels predicted the cardiometabolic risk better than the postprandial response. The authors discuss differences in body composition as a possible explanation.

Networking is urgently required to improve the routine diagnostic assessment and clinical treatment of obese individuals. Thomas Reinehr [7] provides an overview of activities of the German Working Group of Obesity in Childhood and Adolescence. Readers can compare the activities of this active group to the progress that they themselves have witnessed in their respective countries. We encourage submissions that describe national networking activities so that we can all benefit from successful venues or accomplishments.

Martin Fried et al. [8] present the first European guidelines to be published in OBesity Facts. At the same time, the article represents the first attempt to come up with interdisciplinary European guidelines on surgery of severe obesity compiled by the Bariatric Scientific Collaborative Group, which was appointed through joint effort of the major European scientific societies. The guidelines cover topics such as bariatric surgery among the young and the old, techniques and the follow-up period.

We are particularly grateful to all editors, authors and reviewers for their excellent work and generous help in launching our new journal!

Enjoy reading this first issue of OBESITY FACTS!

\section{References}

1 Engeli S: Peripheral metabolic effects of endocannabinoids and cannabinoid receptor blockade. Obesity Facts 2008:1(1):8-15.

2 Hilbert A, Ried J, Schneider D, Juttner C, Sosna M, Dabrock P, Lingenfelder M, Voit W, Rief W, Hebebrand J: Primary prevention of childhood obesity: an interdisciplinary analysis. Obesity Facts 2008: 1(1):16-25.

3 Hinney A, Hebebrand, J: Polygenic obesity in humans. Obesity Facts 2008:1(1):35-42.
4 Frayling TM, Timpson NJ, Weedon MN, Zeggini E, Freathy RM, Lindgren CM, Perry JR, Elliott KS, Lango H, Rayner NW, Shields B, Harries LW, Barrett JC, Ellard S, Groves CJ, Knight B, Patch AM, Ness AR, Ebrahim S, Lawlor DA, Ring SM, Ben-Shlomo Y, Jarvelin MR, Sovio U, Bennett AJ, Melzer D, Ferrucci L, Loos RJ, Barroso I, Wareham NJ, Karpe F, Owen KR, Cardon LR, Walker M, Hitman GA, Palmer CN, Doney AS, Morris AD, Smith GD, Hattersley AT, McCarthy MI: A common variant in the FTO gene is associated with body mass index and predisposes to childhood and adult obesity. Science 2007; 316(5826):889-894.

5 Fischer J, Emmerling C, Rüther U: On the History of Fto. Obesity Facts 2008:1(1):43-44.
6 Hitze B, Rubin D, Helwig U, Schrezenmeir J, BosyWestphal A, Müller MJ: Postprandial triglyceride response in men: role of overweight, abdominal fat and nutrition. Obesity Facts 2008:1(1):45-51.

7 Reinehr T, Holl RH, Wabitsch M: The German Working Group of Childhood and Adolescent Obesity (AGA): improving the quality of care for overweight and obese children in Germany. Obesity Facts 2008:1(1):26-32.

8 Fried M, Hainer V, Basdevant A, Buchwald H, Deitel M, Finer N, Greve JWM, Horber F, MathusVliegen E, Scopinaro N, Steffen R, Tsigos C, Weiner R, Widhalm K: Interdisciplinary European guidelines on surgery of severe obesity. Obesity Facts 2008:1(1):52-59. 